\title{
DRĘCZENIE RÓWIEŚNIKÓW JAKO STRATEGIA OSIĄGANIA WŁASNYCH CELÓW W ŚWIETLE BADAŃ NAD SPOŁECZNĄ DOMINACJĄ I DZIAŁANIAMI PRZYMUSZAJĄCYMI
}

\section{PEER BULLYING AS A STRATEGY FOR ACHIEVING INDIVIDUAL GOALS IN THE LIGHT OF SOCIAL DOMINATION AND COERCIVE ACTIONS STUDIES}

\author{
Aleksandra Tłuściak-Deliowska ${ }^{1(\mathrm{~B}, \mathrm{D}, \mathrm{E}, \mathrm{F})}$
}

${ }^{1}$ Akademia Pedagogiki Specjalnej im. Marii Grzegorzewskiej w Warszawie

Tłuściak-Deliowska A. (2017), Dręczenie rówieśników jako strategia osiagania własnych celów w świetle badań nad społecznq dominacją i działaniami przymuszającymi. Rozprawy Społeczne, 11 (2), s. 7-13.

Wkład autorów:

A. Zaplanowanie badań

B. Zebranie danych

C. Dane - analiza i statystyki

D. Interpretacja danych

E. Przygotowanie artykułu

F. Wyszukiwanie i analiza literatury

G. Zebranie funduszy
Tabele: 0

Ryciny: 0

Literatura: 30

Otrzymano: 09.12.2016

Zaakceptowano: 19.01.2017

\begin{abstract}
Streszczenie
Przedmiotem tekstu jest analiza strategicznej strony dręczenia rówieśniczego. Punktem wyjścia do rozważań jest konstatacja, że coraz częściej różni autorzy i badacze tego fenomenu dochodzą do wniosku, że działania sprawcy dręczenia mają charakter wyraźnie instrumentalny i zaplanowany. W tekście uzasadniam potrzebę takiego przesunięcia punktu ciężkości w zakresie oglądu tego zjawiska koncentrując się szczególnie na zagadnieniu dominacji społecznej oraz funkcji poszczególnych zachowań agresywnych oraz dokonuję przeglądu prac badawczych, które dostarczają (w sposób bezpośredni i pośredni) dowodów na potwierdzenie tych założeń. Na zakończenie przywołuję koncepcję działań przymuszających (coercive actions) opracowaną przez Jamesa T. Tedeschiego i Richarda B. Felsona, za sprawą której mogą być wyjaśniane instrumentalne działania agresywne występujące w bullyingu.
\end{abstract}

Słowa kluczowe: bullying, przemoc rówieśnicza, dręczenie, agresja instrumentalna, działania przymuszające, dominacja społeczna

\section{Summary}

The aim of this paper is to analyze the strategic side of the peer bullying phenomenon. The starting point for considerations is the observation that more and more authors and researchers in this area come to the conclusion that the behaviours of bullies are clearly instrumental and planned. The text justifies the need for shifting emphasis in the overview of the phenomenon by focusing particularly on the issue of social dominance and the function of aggressive behaviours as well as a review of empirical study that provide (direct and indirect) evidence to support these assumptions. At the end, the concept of coercive actions developed by James T. Tedeschi and Richard B. Felson is mentioned, through which instrumental aggression occurring in bullying can be explained.

Keywords: bullying, peer violence, instrumental aggression, coercive actions, social dominance

\section{Specyfika dręczenia rówieśniczego i jego formy - uwagi wstępne}

Bullying, nazywany dręczeniem szkolnym, rówieśniczym tyranizowaniem, czy nękaniem, będąc przedmiotem analiz od początku konceptualizowany był jako specyficzny rodzaj przemocy rówieśniczej zawierający w sobie różne formy zachowań agresywnych. Istota zjawiska dręczenia konstytuuje się w splocie trzech cech dystynktywnych. Po pierwsze, cechą dręczenia jest intencjonalność działań sprawcy, który podejmuje działanie celowo, z zamiarem skrzywdzenia ofiary. Po drugie, wskazuje się na dysproporcję sił między sprawcą a ofiarą. Może mieć ona charakter fizyczny (siła fizyczna, postura, itp.), czy sprowadzający się do pewnych zdolności jednostki, jednakże o wiele ważniejsza może być dysproporcja psychologiczna. W dręczeniu występuje niemożność dowolnej zamiany ról. Szczególnie w trudnej sytuacji jest ofiara, bowiem ma niewielkie szanse na wyjście $\mathrm{z}$ tej roli. Po trzecie, w przypadku dręczenia mamy do czynienia z powtarzalnością zachowań w czasie (Olweus 2010). Przy czym, te zachowania mogą być zróżnicowane pod względem formy i intensywności.

Adres korespondencyjny: Aleksandra Tłuściak-Deliowska, Akademia Pedagogiki Specjalnej im. M. Grzegorzewskiej w Warszawie, Wydział Nauk Pedagogicznych, Instytut Pedagogiki, ul. Szczęśliwicka 40, 02-353 Warszawa, e-mail: adeliowska@aps.edu.pl, tel.: 225893600 wew. 3436 Copyright by: Państwowa Szkoła Wyższa im. Papieża Jana Pawła II w Białej Podlaskiej, Aleksandra Tłuściak-Deliowska

Czasopismo Open Access, wszystkie artykuły udostępniane są na mocy licencji Creative Commons Uznanie autorstwa-użycie niekomercyjne-na tych samych warunkach 4.0 Międzynarodowe (CC BY-NC-SA 4.0, http://creativecommons.org/licenses/by-nc-sa/4.0/). 
Dręczenie może przybierać różne postaci. Najczęściej wyróżnia się cztery formy: dręczenie fizyczne, znęcanie werbalne, wykluczenie społeczne i cyberbullying. Znęcanie fizyczne odnosi się do jawnej agresji fizycznej, która może przejawiać się $\mathrm{w}$ postaci bicia, popychania, kopania, plucia. Werbalne zastraszanie zawiera $\mathrm{w}$ sobie zachowania o charakterze jawnej agresji słownej obejmującej wyzwiska, przezywanie, wyśmiewanie. Wykluczenie społeczne odnosi się do sytuacji, w której sprawca np. manipuluje relacjami społecznymi w taki sposób, by pogorszyć pozycję społeczną ofiary w grupie rówieśniczej. Do tej formy zaliczane są takie zachowania agresywne, jak rozsiewanie plotek, ignorowanie, izolowanie, nastawianie grupy przeciw jednostce. W ostatnim czasie za sprawą rozwoju nowoczesnych technologii komunikacyjnych, dręczenie zostało poszerzone o działania wykorzystujące te narzędzia. Stąd też mowa o cyberbullyingu, który przejawiać się może na różne sposoby, np. upublicznianie za pomoca elektronicznych narzędzi komunikacyjnych poniżających materiałów na temat rówieśnika, nękanie ofiary niechcianymi wiadomościami, usuwanie z listy kontaktów, itp. (Pyżalski 2012). Przy czym, pamiętać należy, iż te formy dręczenia nie stanowią wyizolowanych "bytów", a zatem jeden sprawca dręczenia może podejmować się różnych zachowań agresywnych mieszczących się w każdej z wyżej wymienionych form.

Szczegółowa analiza repertuaru zachowań agresywnych uczniów będących przejawami dręczenia rówieśniczego podyktowana jest najczęściej potrzebą sprawnej orientacji w tych zachowaniach, za sprawą której możliwe będzie podjęcie szybkiej interwencji i przygotowanie efektywnych oddziaływań profilaktyczno-wychowawczych. W niniejszym tekście chciałabym jednak odejść od takiego, "typowego" w mojej ocenie podejścia, na rzecz zwrócenia uwagi na przyczyny wyboru konkretnego działania, a zatem na stronę motywacyjno-funkcjonalną tych działań. Zatem nie chcę koncentrować się na wyszczególnianiu ,jakie zachowania” składają się na bullying i czym się charakteryzują, tylko raczej rozważyć odpowiedź na pytanie: „dlaczego akurat takie zachowania”? Chcę skupić się bardziej na funkcji danego zachowania i jego znaczeniu, na efekcie uzyskiwanym przez sprawcę. Uchwycenie tego problemu w badaniach empirycznych nie jest łatwe i raczej też nie jest podejmowane wprost, jednakże uważam, że niektóre $\mathrm{z}$ dotychczasowych prac empirycznych, jak i koncepcyjnych, będą mogły „rzucić nieco światła" na tą stronę analizowanego zjawiska. Punktem wyjścia do rozważań jest także konstatacja, że coraz częściej w ostatnim czasie różni autorzy i badacze dochodzą do wniosku, że działania sprawcy dręczenia mają charakter wyraźnie instrumentalny i zaplanowany (zob. Salmivalli, Peets 2009; Sutton i in. 2001; Volk i in. 2014).W dalszej części uzasadnię potrzebę takiego przesunięcia punktu ciężkości w zakresie oglądu tego fenomenu oraz dokonam przeglądu prac, które mogą dostarczyć stosownych odpowiedzi, czy wyjaśnień. Ponadto, przywołam koncepcję, za sprawą której te zachowania mogą być w mojej ocenie wyjaśniane - chodzi o koncepcję działań przymuszających (ang. coercive actions) opracowaną przez Jamesa T. Tedeschiego i Richarda B. Felsona (1994).

\section{Kim są młodzi ludzie, którzy prześladują swoich rówieśników?}

Dan Olweus (1993) na podstawie swoich pionierskich badań nad bullyingiem stwierdził, że sprawcy dręczenia charakteryzują się nad wyraz niskim lub co najwyżej przeciętnym poziomem strachu i niepewności. Łatwo się złoszczą, szydzą z innych. Potrafią także wykorzystywać innych uczniów do „niegodziwych”, niecnych czynów. Badacz stwierdził, że dręczycielami częściej są chłopcy niż dziewczynki, jednakże formy, w jakich wyraża się dręczenie dziewcząt trudniej zaobserwować. Stwierdził także wówczas, iż na temat dziewcząt w roli prześladowczyń, niewiele wiadomo, stąd też przedstawione charakterystyki dotyczą głównie chłopców. Ponadto, chłopcy - sprawcy są silniejsi fizycznie od swoich kolegów oraz mają dobrą koordynację psychoruchową, co szczególnie uwidacznia się w sporcie i podczas bójek. Mają potrzebę dominowania i tyranizowania innych. Chełpią się faktyczną lub fikcyjną władzą nad innymi uczniami. Mają trudności z przystosowaniem się do panujących norm i zasad, stąd też przejawiają nie tylko agresję, ale także inne zachowania łamiące normy, takie jak picie alkoholu, chuligaństwo. Zachowania agresywne przejawiają nie tylko wobec rówieśników, ale także wobec rodziców i nauczycieli. Początkowe badania Dana Olweusa sugerowały zatem, że przejawianie zachowań agresywnych przez sprawców dręczenia świadczy o brakach w zakresie umiejętności społecznych, nieumiejętności kontrolowania emocji, czy też jest początkiem rozwoju osobowości antyspołecznej.

Kolejne badania przyczyniły się do przyrostu danych empirycznych na temat właściwości sprawcy i za ich sprawą niektóre pierwotne ustalenia zostały nieco zweryfikowane. Przykładowo, gdy skoncentrujemy na się agresji relacyjnej, uświadomimy sobie fakt, że skuteczne stosowanie takich pośrednich form agresji wymaga jednak dobrej orientacji w relacjach społecznych, a także i kompetencji z tym związanych, co pozostaje w sprzeczności z powyższymi, początkowymi ustaleniami Dana Olweusa na temat sprawcy. Jak wynika z przeglądu literatury dokonanego przez Claire F. Gerandeau i Antoniusa H.N. Cillessena (2006), sprawcy dręczenia posiadają rozwinięte kompetencje społeczne, co najmniej przeciętną inteligencję społeczną i to za ich sprawą podejmują się dręczenia innych.

Clayton R. Cook i współpracownicy (2010) dokonali metaanalizy 1622 studiów empirycznych prowadzonych od 1970 roku w zakresie problematyki dręczenia szkolnego. Zidentyfikowali 1622 dostępnych badań, z czego analizom poddali 153 ze względu na przyjęte warunki analiz, m.in. przedmiotem badań musiały być predyktory wiktymizacji lub sprawstwa dręczenia oraz dane powinny mieć charakter ilościowy w celu możliwości obliczenia wielkości efektu. Na tej podstawie udało się zaktualizować profil „typowego dręczyciela”. Jest to uczeń, który przejawia zachowania eksternalizacyjne (agresja, przeciwstawianie się i opór wobec otoczenia, buntowniczość, nieposłuszeństwo, destruk- 
tywność, wybuchowość), przy czym może mieć także objawy zaburzeń internalizacyjnych, ponadto posiada dobrze rozwinięte umiejętności społeczne, jak również wysokie osiągnięcia szkolne, ma negatywne postawy i przekonania wobec innych, ma problemy z rozwiązywaniem problemów interpersonalnych, pochodzi z rodziny, którą można określić jako konfliktowa i o niskiej rodzicielskiej kontroli, postrzega szkołę przez pryzmat negatywnej atmosfery w niej panującej.

Na tejpodstawie można stwierdzić, że „profil” sprawcy dręczenia nie jest homogeniczny. Dlatego też, może zamiast koncentrować się na cechach tych uczniów, co jest rozwiązaniem powszechnie stosowanym w psychologicznych pracach badawczych i pedagogicznych o charakterze aplikacyjnym, trzeba rozpatrzeć ich motywację, czy też ewentualną funkcję społeczną, jaką pełni dla nich prześladowanie swoich rówieśników?

\section{Bullying i społeczna dominacja w grupie rówieśniczej}

Za przyjęciem zaproponowanego w niniejszym tekście kierunku rozważań przemawia także fakt, że prześladowanie rówieśników nie odbywa się gdzieś w ukryciu. Wręcz przeciwnie, bullying cechuje to, że wiedzą o nim nie tylko napastnicy i ich ofiary. Wyniki różnych badań (Pepler, Craig 1995; Salmivalli i in. 1996), w tym polskich (Komendant-Brodowska 2014a; Tłuściak-Deliowska 2013a) dowodzą, że w ok. $80 \%$ incydentów obecni są inni członkowie grupy rówieśniczej/klasy szkolnej. Obserwatorzy mogą odgrywać w całej sytuacji różne role, wśród których wyróżnia się (1) asystentów agresora, którzy sami co prawda nie inicjują aktów agresji, ale gdy rozpocznie je ktoś inny, dołączają i pomagają agresorowi, (2) wzmacniaczy prześladowcy, czyli uczniów, którzy nie dołączają do sprawcy, lecz dają mu wiele wzmocnień pozytywnych poprzez okazanie aprobaty dla jego zachowania, np. dopingowanie, śmianie się, zachęcające gesty, (3) outsiderów, czyli uczniów, którzy ani nie pomagają sprawcy, nie wzmacniają go, ale też nie bronią ofiary, starają się pozostać bierni i (w swoim mniemaniu) neutralni, oraz (4) obrońców, a zatem uczniów, którzy pomagają na różne sposoby prześladowanemu rówieśnikowi (por. Salmivalli i in. 1996; Tłuściak-Deliowska 2013b; Komendant-Brodowska 2014ab).

Kwestia obecności innych uczniów przy sytuacjach przemocy rówieśniczej jest o tyle newralgiczna, że zachowanie świadków ma znaczenie po pierwsze - dla zachowań sprawcy, po drugie - dla całego zjawiska dręczenia, po trzecie - dla kondycji psychicznej ofiary. Na pierwszym wątku chciałabym się szczególnie skoncentrować. Jak stwierdza Agata Komendant-Brodowska (2014b, s. 47-48), cały proces dręczenia jest „spektaklem” aranżowanym dla świadków. Dzięki obecności uczniów-świadków i ich zachowaniom głównie wzmacniających sprawcę, uczeń dręczący może zademonstrować, czy też potwierdzić swój status społeczny w grupie rówieśniczej oznaczający dla niego władzę, prestiż, czyli społeczną dominację.
Dominacja społeczna jest podstawową cechą relacji interpersonalnych ze względu na naturalną asymetrię między jednostkami. Zwróciła na to uwage Patricia H. Hawley (1999), która przedstawiła model ludzkiej dominacji społecznej (strategii pozyskiwania zasobów), znany obecnie pod nazwą teorii kontroli zasobów (ang. resources control theory, RCT; Hawley i in. 2007). Generalnie koncepcja dominacji wywodzi się z etologii i przywołuje się tutaj jako bazową pracę Thorleifa Schjelderup-Ebbe'a z 1922 roku (za: Hawley 1999, s. 98) opisującą linearną kolejność dziobania u ptactwa domowego. Z obserwacji przywołanego autora wynikało, że zwierzęta te czasami walczą o status i pozycję w stadzie bardziej agresywnie, niż o jedzenie, czy partnera/partnerkę. Ponadto, ów „porządek dziobania” sprowadza się do tego, że im niżej kura znajduje się w hierarchii stada, tym częściej jest dziobana, gdyż dziobią ją kury znajdujące się wyżej od niej w tej hierarchii. Jednocześnie im kura znajduje się wyżej w hierarchii stada, tym częściej dziobie inne, te znajdujące się niżej od niej. Ta koncepcja była wielokrotnie używana do wyjaśniania działania organizacji, czy utrzymywania stabilności struktury socjalnej w wielu grupach zwierząt i choć krytykowana, dostarcza jednak dobrych narzędzi do wytłumaczenia niektórych aspektów społecznej dynamiki grupy.

W odniesieniu do zachowań interpersonalnych o dominacji społecznej wnioskuje się wówczas, gdy agresywne zachowanie jednostki skutkuje uległością i podporządkowaniem drugiej osoby. Zdaniem Patrici H. Hawley (1999; Hawley i in. 2007) taka dominacja oznacza kontrolowanie pewnych zbiorów (źródeł), dzięki wygranej rywalizacji o zasoby cenione acz deficytowe. W trakcie rywalizacji jednostki mogą wykorzystywać strategie prospołeczne bazujące na kooperacji oraz strategie przymusu, czyli mające charakter działań agresywnych i aspołecznych. Zasoby z kolei mogą mieć charakter materialny (np. zabawki, pieniądze, gadżety), społeczny (np. sojusznicy, partnerzy, koledzy), czy informacyjny (ułatwiający osiągnięcie czegoś). Odnosząc to do nastolatków osoba, która ma wysoką kontrolę zasobów (dominację społeczną) to ta, która przykładowo, ma najnowsze gadżety technologiczne, traktowana jest z szacunkiem (respektem), czy ma wielu popleczników. Przy czym, przywołana autorka zwraca uwagę, że jej rozumienie dominacji społecznej z jednej strony ma elementy wspólne $\mathrm{z}$ dominacją $\mathrm{w}$ ujęciu psychologii osobowości, która przypisuje taką właściwość pewnym jednostkom, jednakże cechy jednostki same w sobie nie stanowią jeszcze o społecznej dominacji. Ponadto, odżegnuje się od redukcjonistycznego stanowiska socjobiologii rozpatrującego zachowania społeczne i wskazującego na dominację jako cechę zakodowaną genetycznie i związaną z siłą doboru naturalnego. $\mathrm{Na}$ rzecz zwrócenia uwagi, że istotnym mediatorem czy kreatorem dominacji społecznej jest obecność innych, a zatem to za sprawą grupy owa dominacja jest regulowana. W takiej sytuacji mamy do czynienia $\mathrm{z}$ balansowaniem między interesem jednostki a inte- 
resem innych, zachowaniami jednostki a zachowaniami grupy. $Z$ tego punktu widzenia zajmowanie się kwestią społecznej dominacji w kontekście dręczenia zdaje się być wysoce uprawomocnione, co więcej - ma potwierdzenie empiryczne.

Tracy Vaillancourt, Shelley Hymell i Patricia McDougall (2003) przeprowadziły w Kanadzie badania z udziałem 555 uczniów w wieku 11-17 lat, których celem było określenie związku między bullyingiem, władzą i statusem społecznym (pozycją w grupie), ale także dokonanie charakterystyki uczniów-sprawców z uwzględnieniem różnych właściwości dotyczących ich ogólnego funkcjonowania. Wykorzystano metodę nominacji rówieśniczej oraz metodę self-report. Na podstawie uzyskanych rezultatów badaczki stwierdziły, że grupa sprawców jest bardzo zróżnicowana pod względem poszczególnych charakterystyk. Niektórzy sprawcy dręczenia byli nielubiani przez rówieśników i postrzegani jako agresywni, jednakże inni dręczyciele byli lubiani przez pozostałych, popularni, zajmujący wysokie pozycje w grupie, charakteryzowali się zdolnościami przywódczymi, czy innymi, liczącymi się w grupie kompetencjami społecznymi. Okazało się także, że ci uczniowie postrzegają siebie pozytywnie i są zadowoleni ze swoich relacji interpersonalnych z rówieśnikami. Gdy dokonano klasyfikacji sprawców dręczenia z punktu widzenia ich społecznej dominacji, okazało się, że ci, którzy identyfikowani byli przez rówieśników jako dominujący i posiadający władzę (ponad połowa sprawców), byli jednocześnie bardziej popularni, bardziej lubiani i częściej stosowali psychologiczne i relacyjne formy agresji niż pozostali sprawcy. Co więcej, tym uczniom przypisywano także więcej innych pozytywnych cech, np. rówieśnicy postrzegali ich jako atrakcyjnych fizycznie, czy noszących modne ubrania.

Podobnych rezultatów dostarczyły badania Jelle J. Sijtsema i współpracowników (2009), w których udział wzięli uczniowie w wieku 10-11 i 14-15 lat. Także w tym przypadku wykazano, że dręczenie rówieśników utożsamiane jest $\mathrm{z}$ prestiżem rozumianym jako postrzegana popularność w grupie rówieśniczej (jednakże nie jest to równoznaczne z lubieniem). Dominacja społeczna sprawców wiązała się z częstszym stosowaniem proaktywnej agresji, z kolei dla uczniów, którzy byli ofiarami dręczenia, charakterystyczne były wręcz przeciwstawne cechy.

W badaniach Tjeert Olthof i współpracowników (2011), w których udział wzięło 1129 dzieci w wieku 9-12 lat, badani uczniowie zostali sklasyfikowani według roli jaką pełnią $\mathrm{w}$ dręczeniu szkolnym oraz według stosowanej strategii przymuszającej versus prospołecznej zapewniającej dominację społeczną w grupie. Okazało się, że w uczniowie będący sprawcami dręczenia, w przeciwieństwie do niedręczących, stosowali znacznie częściej obie strategie, a zatem o charakterze przymuszającym, ale także prospołecznym. Dla sprawców inicjujących zachowania agresywne (ang. ringleader) charakterystyczna była dominacja społeczna w grupie oraz wysokie pra- gnienie i dążenie do tej dominacji. Ogólnie badacze ci stwierdzili, że zgromadzony materiał empiryczny stanowi mocne poparcie dla stanowiska mówiącego o tym, że bullying jest strategicznym działaniem zorientowanym na zapewnienie i utrzymanie dominacji społecznej.

Z przytoczonych badań wynika zatem, że dręczenie rówieśników $w$ wieku szkolnym jest związane z hierarchią statusu. Ów status wewnątrzgrupowy oznacza względną ważność jednostki w porównaniu z innymi członkami grupy rówieśniczej. Status ten gwarantuje dominację społeczną i wyraża się stopniem, w jakim jednostka obdarzana jest uwagą, respektem i prestiżem. Sprawcy dręczenia motywowani są do dążenia do władzy i osiągnięcia wysokiego statusu w grupie rówieśniczej, starając się przy tym zwiększyć własny zysk, a minimalizować ewentualne straty. Przytoczone badania pokazują, że są oni w tym skuteczni i przez swoich rówieśników postrzegani jako mający władzę i widoczni na tle grupy. W celu zmaksymalizowania swojego zysku sprawca może celowo dobrać ofiarę, która może być łatwym i podatnym na atak celem i jednocześnie stanowić przeciwieństwo sprawcy pod względem pewnych charakterystyk. Atakuje ją wówczas przy świadkach, dzięki czemu grupa obserwatorów (grupa rówieśników) konfrontowana jest z jego „siłą”, co wzmacnia (utrwala) jego wysoką pozycję w grupie. Z kolei ów status przekłada się na materialne, czy społeczne zasoby, które postrzegane są przez współczesnych badaczy jako kluczowy czynnik dominacji społecznej (por. Hawley 1999; Pellegrini 2008).

Ponadto, skoro sprawca działa motywowany potrzebą dominacji i władzy, ofiarą może zostać także każda osoba, która odmawia poddania się „władzy” dręczyciela lub mu zagraża ze względu np. na rosnącą popularność, a zatem ze względu na coraz wyższą pozycję w hierarchii. Aby utrzymać swój status w grupie, dominujący uczeń musi kontrolować innych rówieśników. W ten sam sposób, jak dyktatorskie reżimy dławią wszelki opór, tak w grupie rówieśniczej, w której są hierarchiczne relacje, lider nie może tolerować żadnej oporności na jego wpływ (por. Garandeau, Cillessen 2006).

Zwrócić uwagę także należy na fakt, że ustanowienie hierarchii statusu i jej utrzymywanie za sprawą dręczenia rówieśniczego w obrębie konkretnej grupy, może pełnić funkcję adaptacyjną nie tylko dla dominującego sprawcy, ale także dla większości grupy, ponieważ przesądza o pewnym status quo. Hierarchia dominacji pozwala zorientować się młodzieży w sieci relacji społecznych, stanowi uporządkowaną społecznie scenę, a zatem przekłada się w pewnym sensie na poczucie bezpieczeństwa i oznacza przewidywalność pewnego rodzaju zachowań w wykonaniu poszczególnych uczniów. Dodatkowo, młodzi ludzie tym sposobem uczą się, jak ustalać hierarchię w grupie i co przesądza o poszczególnych pozycjach (por. Juvonen i Graham 2014). 


\section{Raz jeszcze o rodzajach zachowań agresywnych konstytuujących dręczenie}

Działania podejmowane przez sprawcę mogą mieć charakter bezpośredni, jawny lub/i pośredni, ukryty. Biorąc pod uwagę sposób działania należy stwierdzić, że w pierwszym przypadku sprawca bezpośrednio konfrontuje ofiarę, atakując ją fizycznie lub werbalnie. $\mathrm{W}$ bullyingu pośrednim sprawca wykorzystuje do realizacji aktów agresji np. inne osoby, manipulując ich zachowaniem. Zatem narzędziem ataku może być grupa rówieśnicza. Środkiem wykorzystanym do ataku mogą być także nowe technologie, czyli wówczas mamy do czynienia z cyberbullyingiem. Na podstawie licznych badań z zakresu zachowań agresywnych w ogóle i związanych z dręczeniem ustalono, że chłopcy wykorzystują zarówno bezpośrednie i pośrednie formy agresji do prześladowania innych, a dziewczęta preferują głównie formy pośrednie (Salmivalli, Peets 2009; Olthof i in. 2011). Eleanor Maccoby (2004) stwierdza, że agresja chłopców jest często (ale też nie zawsze) kierowana na osoby spoza grupy własnej, tymczasem zachowania agresywne dziewcząt mają charakter wewnątrzgrupowy i najczęściej kierowane są na członków grupy własnej. Bullying w przypadku chłopców jest środkiem zapewniającym wzrost „wewnętrznej siły” grupy i spójności, a także solidaryzowania się w różnych sytuacjach, co wyrażać się może w podejmowaniu bardziej ryzykownych, ekstremalnych form bullyingu w celu scementowania powstałych koalicji.

Mitchell Prinstein i Antonius H.N. Cillessen (2003) rozważając związek agresji z dominacją społeczną, zwracają uwagę, że studia etologiczne podejmujące tą problematykę, koncentrowały się wyłącznie na takich manifestacjach zachowań agresywnych, które wspólne są dla ludzi i innych gatunków, a zatem analizowano głównie zachowania bezpośrednie, konfrontacyjne, takie jak agresja fizyczna, czy werbalna. Te zachowania w dość oczywisty sposób gwarantują dominację w grupie, przesądzają o sile i przewadze.

W przeciwieństwie do otwartych form agresywnych, agresja pośrednia zawierająca niefizyczne środki powodujące krzywdę (czyli np. złośliwe plotki, wykluczanie z grupy i wspólnych aktywności, itp.) ma charakter mniej konfrontacyjny niż np. bójka. Przy czym, Mitchell Prinstein i Antonius H.N. Cillessen (2003) dokonują jeszcze wewnętrznego zróżnicowania agresji pośredniej na agresję „reputacyjną” (zwaną także społeczną) i agresję relacyjną. Agresja „reputacyjna” sprowadza się do próby zniszczenia czyjejś społecznej reputacji, co oznaczać będzie jej spadek w hierarchii społecznej grupy, podczas gdy agresja relacyjna oznacza wykorzystanie relacji społecznych do spowodowania szkody innych. W przypadku agresji relacyjnej chodzi np. o zniszczenie relacji przyjacielskiej jakiejś osoby lub/i uczuć związanych z procesem przynależności do grupy. W mojej ocenie, agresja reputacyjna związana jest z ruchliwością pionową (wertykalną) w strukturze grupy, zaś relacyjna odnosi się do ruchliwości poziomej (horyzontalnej).
Z badań Hongling Xie i współpracowników (2002) przeprowadzonych wśród 475 nastolatków (średnia wieku 13,4 lat) wynika, że reputacyjna agresja jako jedyna forma agresji związana jest z centralnością jednostki w sieci społecznej (więcej o zagadnieniu analizy sieciowej w kontekście dręczenia szkolnego: Tłuściak-Deliowska 2014). Taki wynik doprowadził badaczy do konstatacji, że tylko nastolatkowie istotni (centralni) w klikach (podgrupach) potrafią efektywnie wykorzystać tą formę agresji. Mitchell Prinstein i Antonius H.N. Cillessen (2003) stwierdzają również, że relacyjna i reputacyjna agresja - obok agresji fizycznej - mogą zagwarantować społeczną dominację. Przy czym przyjmują, że agresja relacyjna jest najbardziej skuteczna w specyficznych klikach przyjacielskich, a agresja reputacyjna ma największy potencjał w nieco większym społecznym kontekście, który umożliwia manipulację pozycją osoby i jej spadek w ogólnej hierarchii grupy. Reputacyjną agresją posłużyć się mogą tylko osoby zajmujące wysoką pozycję w grupie rówieśniczej, co jest dodatkowo nagradzane i wzmacniane przez pozostałych członków grupy. Przy czym, przywołani badacze na podstawie swoich longitudinalnych badań stwierdzają jednak, że tego typu agresja służy głównie podtrzymaniu ich statusu, raczej niż jego zdobyciu. W przeciwieństwie - osoby zajmujące niskie pozycje w grupie, raczej nie inicjują tego typu zachowań. Z punktu widzenia nastolatków doświadczających zachowań agresywnych zauważyć należy, że ofiarą agresji reputacyjnej mogą być tylko osoby zajmujące względnie wysokie pozycje, czyli stanowiące zagrożenie dla dominującej osoby i mogące swój wysoki status w hierarchii utracić. Z kolei zachowania agresywne o charakterze relacyjnym, czyli takie, które nie szkodzą ogólnej hierarchii w grupie, nie są podejmowane wobec osób $\mathrm{z}$ wysokim statusem grupowym. Ponadto, na podstawie serii badań badacze ci stwierdzili, że wykorzystanie w sposób instrumentalny (proaktywny) agresji fizycznej, relacyjnej i tej atakującej status hierarchii związane było z popularnością (prestiżem) jednostki w grupie, zaś wykorzystanie tych form w sposób reaktywny, nie przekładało się na ów prestiż.

\section{Koncepcja „działań przymuszających” Jamesa T. Tedeschiego i Richarda B. Felsona}

Biorąc pod uwagę powyższe rozważania, na zakończenie chcę przywołać koncepcję zachowań agresywnych, która w mojej ocenie może być przydatna w odniesieniu do interpretacji bullyingu i poszczególnych zachowań go tworzących, bowiem koncentruje się ona na analizie działań instrumentalnych.

James T. Tedeschi i i Richard B. Felson są autorami modelu działań przymuszających na gruncie interakcjonizmu społecznego (1994). Definiują oni przymus jako działanie podjęte z intencją wyrządzenia szkody drugiej osoby lub wymuszenia jej posłuszeństwa (1994, s. 168), jest to zatem nieco inne określenie zachowań agresywnych ze zwróceniem uwagi na funkcję tego działania. Działania przymuszające 
traktowane są jako forma wpływu społecznego, co zwraca uwagę na społeczną naturę tego typu zachowań. Autorzy tego modelu założyli, że strategiom przymusu stosowanym przez sprawce agresji przyświecają trzy główne cele: (1) kontrola zachowania innych osób (manipulacja zachowaniem), (2) zapewnienie lub/i przywrócenie sprawiedliwości (ukaranie, zemsta), (3) potwierdzenie i ochrona własnej tożsamości/statusu (Tedeschi, Felson 1994, s. 348). Działania przymuszające (czyli działania agresywne) konceptualizowane są zatem jako rezultat procesu podejmowania decyzji, w którym najpierw sprawca postanawia zastosować którąś ze strategii opartych na przymusie, a następnie wybiera jej formę, która jego zdaniem okaże się najbardziej skuteczna w osiągnięciu zamierzonego celu.

Według tej teorii do wyboru są trzy najważniejsze formy przymusu: (1) groźba warunkowa, która oznacza zakomunikowanie intencji wyrządzenia krzywdy drugiej osobie pod warunkiem odmowy spełnienia żądania agresora, (2) użycie siły fizycznej, czyli zastosowanie kontaktu fizycznego w celu zmuszenia jednostki do określonego zachowania lub powstrzymania go przed nim, (3) kara, czyli czynność będąca pewną dolegliwością dla drugiej osoby. Wybór strategii przymusu determinuje intencja osiągnięcia efektu proksymalnego, czyli bezpośredniego, co jednak motywowane jest przez zamiar osiągnięcia konkretnego celu finalnego (Tedeschi, Felson 1994; zob. także: Krahe 2006, s. 46; Farnicka i in. 2016, s. 65) Przy czym, autorzy tej koncepcji przyjęli, że decyzja, by zastosować groźbę lub siłę fizyczną, jest stymulowana intencją uzyskania posłuszeństwa obiektu wobec sprawcy lub jego żądań, w efekcie czego jednostka zyskać może jakieś zasoby, bezpieczeństwo czy pozycję. W tym przypadku mamy do czynienia zatem z ustaleniem dominacji społecznej niejako wprost, a więc sięga się po agresję bezpośrednią. Natomiast kara wykonywana jest jako działanie krzywdzące z ostatecznym celem przywrócenia korzystnej sytuacji w percepcji jednostki stosującej przymus, co utożsamione jest z przywróceniem sprawiedliwości. Celem może być także obrona własnego nadrzędnego statusu, czy powstrzymanie kogoś przed wykonaniem konkretnej, niepożądanej z punktu widzenia sprawcy, czynności. W tym sensie jako kara mogą być wykorzystane np. opisane wcześniej - agresja reputacyjna i relacyjna.

Zgodnie $\mathrm{z}$ tą koncepcją jednostka traktowana jest jako osoba świadoma i sprawująca kontrolę nad swoim zasobem reakcji agresywnych oraz zdolna do wyboru nieagresywnych działań. Tego typu założenie pokrywa się ze strategiami stosowanymi przez sprawców dręczenia udokumentowanymi w - przywołanych już w tym tekście - badaniach Tjeert Olthof i współpracowników (2011), gdzie okazało się, że uczniowie dręczący innych stosowali oprócz strategii przymusu, strategie prospołeczne, kooperacyjne.

Jednostka rozważa koszty i korzyści związane z każdą z opcji. Koncepcja działań przymuszających zakłada, że działająca jednostka ma świadomość ist- nienia związku przyczynowego między działaniem przymuszającym powodującym krzywdę a jej wartościami końcowymi. Sprawca bierze zatem pod uwagę subiektywną wartość zamierzonego celu, prawdopodobieństwo jego osiągnięcia za pomocą rozważanego działania oraz wielkość i prawdopodobieństwo poniesienia ewentualnych strat. Dokonanie oceny, jaką strategię wybrać, jest możliwe na podstawie uprzedniego doświadczenia, które jednostka zdobyła działając w podobnych sytuacjach. Dlatego też, jeśli uczeń wcześniej otrzymał wzmocnienie ze strony swoich rówieśników-świadków, istnieje wysokie prawdopodobieństwo, że będzie to zachowanie agresywne powielał, w dodatku w ich obecności.

Podejmowana decyzja o wykorzystaniu strategii przymusu wyzwalana jest także dzięki dostępności skryptu (uogólnionej struktury poznawczej i wykonawczej), bowiem częste stosowanie przymuszającej versus nieprzymuszającej strategii osiągania celów osobistych, powoduje łatwiejsze i szybsze aktywizowanie tych zachowań przymuszających lub nieprzymuszających, które były już wypróbowane (jednorazowo lub wielokrotnie). Decyzja o działaniu przymuszającym, które jest wedle społecznie przyjętych standardów oceniane negatywnie, wiąże się ponadto $\mathrm{z}$ konfrontowaniem go $\mathrm{z}$ uznawanym przez jednostkę systemem wartości, gdyż wyznacza to możliwość jego uzasadnienia (usprawiedliwienia), co wiąże się z ochroną poczucia własnej wartości (zachowanie niezgodne $\mathrm{z}$ uznawanymi wartościami stanowi zagrożenie dla samooceny) (zob. Wysocka 2013, s. 120; Krahe 2006, s. 46-47; Farnicka i in., s. 65). Sprawca dręczenia może być kompetentny w dokonywaniu ocen moralnych swoich czynów, tzn. może mieć świadomość, że prześladowanie swojego rówieśnika jest zachowaniem nieetycznym, ale mimo to, może podejmować się go (pamiętając o swoim zysku) za sprawą restrukturalizacji poznawczej, dzięki której następuje „moralne odłączenie się” (zob. więcej: Tłuściak-Deliowska 2016).

\section{Komentarz końcowy}

Przedstawione ustalenia wspierają założenie, że dręczenie rówieśnicze ma charakter wyraźnie strategiczny, który odzwierciedla dążenie do dominacji społecznej, ustalenie hierarchii statusu, czy też stanowi gwarancję tej dominacji i władzy. Koncentracja na instrumentalnej stronie agresji nie oznacza jednak, że sprawca dręczenia nie użyje agresji reaktywnej, gdy np. zostanie sprowokowany przez swojego rówieśnika. Pozwala jednak zrozumieć, dlaczego tego typu działania są podejmowane i utrzymują się w czasie. Chcąc zaś sformułować implikację praktyczną na podstawie powyższych rozstrzygnięć należy stwierdzić, że skoro bullying stanowi pewną strategię zapewniającą dominację społeczną w grupie, programy profilaktyczne i wychowawcze, by mogły być skuteczne, powinny uwzględniać motywacyjne i funkcjonalne aspekty tego zjawiska. 


\section{Literatura:}

1. Cook C.R., Williams K.R., Guerra N.G., Kim T.E., Sadek S. (2010), Predictors of bullying and victimization in childhood and adolescence: a meta-analytic investigation. School Psychology Quarterly, 2(25), s. 65-83.

2. Farnicka M., Liberska H., Niewiedział D. (2016), Psychologia agresji. Wybrane problemy. PWN, Warszawa.

3. Garandeau C.F., Cillessen A.H.N. (2006), From indirect aggression to invisible aggression: A conceptual view on bullying and peer group manipulation. Aggression and Violent Behavior, 11, s. 612-625.

4. Hawley H.P. (1999), The ontogenesis of social dominance: a strategy-based evolutionary perspective. Developmental Review, 19, s. 97-132.

5. Hawley H.P., Little T.D., Card N.A. (2007), The allure of a mean friend: Relationship quality and processes of aggressive adolescents with prosocial skills. International Journal of Behavioral Development, 31, s. 170-180.

6. Juvonen J., Graham S. (2014), Bullying in Schools: The Power of Bullies and the Plight of Victims. Annual Review of Psychology, 65, s. 159-185.

7. Komendant-Brodowska A. (2014a), Agresja i przemoc szkolna. Raporto stanie badań. Analizy IBE/01/2014, Warszawa.

8. Komendant-Brodowska A. (2014b), Grupowe uwarunkowania przemocy szkolnej. Niepublikowana rozprawa doktorska, Uniwersytet Warszawski, Warszawa.

9. Krahe B. (2006), Agresja. Gdańskie Wydawnictwo Psychologiczne, Gdańsk.

10. Maccoby E. (2004), Aggression in the context of gender development, W: M. Putallaz, K.L. Bierman (eds.), Aggression, antisocial behavior and violence among girls. The Guilford Press, New York, s. 3-22.

11. Olthof T., Goossens F.A., Vermande M.M, Aleva E.A., van der Meulen M. (2011), Bullying as strategic behavior: Relations with desired and acquired dominance in the peer group. Journal of School Psychology, 49, s. 339-359.

12. Olweus D. (1993), Bullying at school: What we know and what we can do. Blackwell Publishing, Malden, MA.

13. Olweus D. (2010), Przemoc w szkołach. Prezentacja na Europejskim Kongresie Przeciwdziałania Przemocy Szkolnej, Warszawa, 15.09.2010.

14. Pellegrini A.D. (2008), The roles of aggressive and affiliate behaviors in resource control: A behavioral ecological perspective. Developmental Review, 28, s. 461-487.

15. Pepler D.J., Craig W. (1995), A peek behind the fence: Naturalistic observation of aggressive children with remote audiovisual recording. Developmental Psychology, 31, s. 548-553.

16. Prinstein M.J., Cillessen A.H.N. (2003), Forms and functions of adolescent peer aggression associated with high levels of peer status. Merrill-Palmer Quarterly, 49, 3, s. 310-342.

17. Pyżalski J. (2012), Agresja elektroniczna i cyberbullying jako nowe ryzykowne zachowania młodzieży. Oficyna Wydawnicza „Impuls”, Kraków.

18. Salmivalli C., Lagerspetz K., Bjorkvist K., Osterman K., Kaukiainen A. (1996), Bullying as a Group Process: Participants Roles and Their Relation to Social Status within the Group. Aggressive Behavior, 22, s. 1-15.

19. Salmivalli C., Peets K. (2009), Preadolescents' peer-relational schemas and social goals across relational contexts. Social Development, 18, s. 817-832.

20. Sijtsema J.J., Veenstra R., Lindenberg S., Salmivalli C. (2009), Empirical test of bullies' status goals: assessing direct goals, aggression and prestige. Aggressive Behavior, 35, s. 57-67.

21. Sutton J., Smith P.K., Swettenham J. (1999), Bullying and theory of mind: A critique of the social skills deficit view of anti-social behavior. Social Development, 8, s. 117-127.

22. Tedeschi J.T., Felson R.B. (1994), Violence, aggression \& coercive actions. American Psychological Association, Washington.

23. Tłuściak-Deliowska A. (2013a), Zaangażowanie gimnazjalistów w przemoc rówieśniczą. Rola bliskich przyjaźni. Wychowanie na co Dzień, 6(237), s. 3-7.

24. Tłuściak-Deliowska A. (2013b), Deklaracje postaw wobec przemocy rówieśniczej wśród gimnazjalistów. Psychologia Rozwojowa, 18(3), s. 75-86.

25. Tłuściak-Deliowska A. (2014), O wykorzystaniu i użyteczności analizy sieci społecznych w badaniu przemocy rówieśniczej w szkole. Teraźniejszość - Człowiek - Edukacja, 3(67), s. 147-159.

26. Tłuściak-Deliowska A. (2016), Moralność i bullying. Edukacja charakteru podstawowym elementem $w$ rozwiązaniu problemu dręczenia rówieśniczego w szkole? Studia z Teorii Wychowania, 7, 1 (14), s. 169-193.

27. Vaillancourt T., Hymel Sh., McDougal P. (2003), Bullying is power: implications for school-based intervention strategies. Journal of Applied School Psychology, 19, s. 157-176.

28. Volk A.A., Dane A.V., Marini Z.A. (2014), What is bullying? A theoretical redefinition. Developmental Review, 34, s. 327-343.

29. Wysocka E. (2013), Agresja w młodym pokoleniu - teoretyczne i empiryczne egzemplifikacje. Pedagogika Społeczna, 2(48), s. 115-136.

30. Xie H., Swift D.J., Cairns B.D., Cairns R.B. (2002), Aggressive behaviors in social interaction and developmental adaptation: A narrative analysis of interpersonal conflicts during early adolescence. Social Development, 11, 205-224. 